IZA DP No. 9747

China's Sex Ratio and Crime:

Behavioral Change or Financial Necessity?

Lisa Cameron

Xin Meng

Dandan Zhang

February 2016 


\title{
China's Sex Ratio and Crime: Behavioral Change or Financial Necessity?
}

\author{
Lisa Cameron \\ Monash University \\ and IZA \\ Xin Meng \\ Australian National University \\ and IZA \\ Dandan Zhang \\ Peking University

\section{Discussion Paper No. 9747 \\ February 2016} \\ IZA \\ P.O. Box 7240 \\ 53072 Bonn \\ Germany \\ Phone: +49-228-3894-0 \\ Fax: +49-228-3894-180 \\ E-mail: iza@iza.org
}

Any opinions expressed here are those of the author(s) and not those of IZA. Research published in this series may include views on policy, but the institute itself takes no institutional policy positions. The IZA research network is committed to the IZA Guiding Principles of Research Integrity.

The Institute for the Study of Labor (IZA) in Bonn is a local and virtual international research center and a place of communication between science, politics and business. IZA is an independent nonprofit organization supported by Deutsche Post Foundation. The center is associated with the University of Bonn and offers a stimulating research environment through its international network, workshops and conferences, data service, project support, research visits and doctoral program. IZA engages in (i) original and internationally competitive research in all fields of labor economics, (ii) development of policy concepts, and (iii) dissemination of research results and concepts to the interested public.

IZA Discussion Papers often represent preliminary work and are circulated to encourage discussion. Citation of such a paper should account for its provisional character. A revised version may be available directly from the author. 


\section{ABSTRACT \\ China's Sex Ratio and Crime: Behavioral Change or Financial Necessity?*}

This paper uses survey and experimental data from prison inmates and comparable noninmates to examine the drivers of rising criminality in China. Consistent with socio-biological research on other species, we find that China's high sex-ratios are associated with greater risk-taking and impatience amongst males. These underlying behavioral impacts explain some part of the increase in criminality. The primary avenue through which the sex-ratio increases crime, however, is the direct pressure on men to appear financially attractive in order to find a partner in the marriage market. These marriage market pressures result in a higher propensity to commit financially rewarding crimes.

JEL Classification: $\quad$ O12, J12

Keywords: crime, marriage markets, risk-taking, time preferences, sex-ratio, one child policy, China

Corresponding author:

Lisa Cameron

Department of Econometrics and Business Statistics

Monash University

3800 Victoria

Australia

E-mail: lisa.cameron@monash.edu

\footnotetext{
* We would like to thank Xiaobo Zhang for providing us with the sex-ratio data. The paper also bene tted from comments from participants at the 2014 University of New South Wales Workshop in Experimental Methods for Social Science and Business; 2015 Shanghai Applied Economics Workshop at Shanghai Univer- sity of Finance and Economics; 6th Workshop on the Economics of Health and Wellbeing, Melbourne, 2015; NBER-CCER Meeting at Peking University, 2015; and seminar participants at Texas A\&M and Monash University.
} 


\section{Introduction}

This paper examines the channels via which China's highly skewed sex-ratio has driven recent large increases in the crime rate. Crime rates in China have increased dramatically - from 7.4 per ten thousand in 1982 to 47.8 per ten thousand in $2014{ }^{1}$ At the same time, large cohorts of "surplus" males are reaching adulthood. Edlund et al. (2013) show that crime rates are indeed higher in Chinese provinces with higher sex-ratios but we do not yet have a clear understanding of the mechanism via which excess males increase crime. Experimental studies of other species find that high sex-ratios (more men than women) increase male-tomale competition and aggression towards females. ${ }^{2}$ The increases in crime may thus reflect behavioral impacts of living in a society as a young male surrounded by many more young men than women. The increased marriage market competition resulting from the high sexratios may also be creating direct incentives for men to commit crime as they seek to gather financial resources to make themselves and/or their children appear a more attractive mate. In this paper we examine the extent to which each of these potential mechanisms contributes to the rapid increase in crime.

Our focus is on rural-urban migrants. Currently more than $40 \%$ of the urban labour force is comprised of such migrants, NBS (2014). As migrants predominantly find marriage partners from their home prefecture - as a result of their relative social and economic disadvantage in the cities and China's system of household registration (hukou) which limits access to services for non-locals - variation across sex-ratios in home prefectures allows us to capture the extent of competition faced by individuals in the marriage market. Rural-urban migrants also constitute a large proportion of Chinese inmates, especially in the industrial centres in the south of the country. We collect experimental and survey data from male prisoners in a prison in Shenzhen where $85 \%$ of inmates are rural-urban migrants and from

\footnotetext{
${ }^{1}$ Source: Zhang (2011)and Law Yearbook of China 2010-2015.

${ }^{2}$ This hypothesis is supported by experimental studies that manipulate the sex-ratio of geographically concentrated populations (for example, of lizards and birds) and observe behavior and survival rates, Le Galliard et al. (2005); Michler et al. (2011). Similar patterns have been described in human populations, Barber (2003); Hudson and Boer (2002) and Wilson and Daly (1985)).
} 
a representative sample of non-inmate migrants from the same city.

We exploit the exogenous geographic variation in China's sex-ratio introduced by the One Child Policy to identify the relationship between sex-ratios and crime. Local sexratios in China are largely a result of the stringency with which the One Child Policy (OCP) has been implemented - which varies substantially across the country in a way that is largely orthogonal to other underlying demographic drivers. We present empirical evidence supporting the exogeneity of sex-ratios below.

We find that the home prefecture sex ratio has a strong association with criminality moving from the naturally occurring sex ratio at birth in humans of about 1.07 (107 males for every 100 females) to our sample mean of 1.14 (a one standard deviation increase) would increase the incarceration rate by about 0.84 percentage points. This is a relatively large effect, corresponding to about a $34 \%$ increase in the probability of being incarcerated for committing a crime. We find that sex-ratios have a large and significant effect on men's behavioral preferences and that these preferences (risk-taking and impatience) in turn affect the propensity for committing crimes. The rise in crime associated with increased risk-taking and impatience is however dwarfed by the direct effect of financial pressures on single men who are competing to find a wife. High sex ratios drive the propensity to commit crimes which have a high financial payoff (such as drug-dealing and theft), not violent crime.

\section{Background}

Crime rates in China have increased more than sixfold over the past three decades. Mirroring this, the arrest rate has more than doubled from 4 per ten thousand in 1988 to 8.3 per ten thousand in 2009 (Zhang et al., 2011). Major socio-economic change is undoubtedly a force behind this increase - extraordinary economic growth and rapidly rising inequality (Gan et

al., 2013); increases in mass rural-urban migration (Zhang, 2011); and erosion of traditional values (Liu, 2005). In addition to the economic changes experienced in China over the past decades, the Chinese people have experienced dramatic change at the level of the family. 
China's One Child Policy was launched in 1979. This policy varied across the country but generally limited couples living in urban areas to having only one child, while most rural areas were allowed a second birth if the first was a girl. The One Child Policy, in combination with China's strong culture of son preference (particularly in rural areas), the availability of ultrasound technology and female infanticide and abandonment has resulted in a highly skewed sex ratio. By 2000 almost 120 boys were born for every 100 girls and by 2010 there were an estimated 30 million "surplus" boys (Zhu et al., 2009). ${ }^{3}$

These surplus men are pouring out of the countryside and into China's industrial cities in search of work. They are predominantly of low socioeconomic class, and concerns have been expressed that their lack of marriageability and consequent marginalization in society may lead to anti-social behavior and violence, Hudson and Boer (2002). Young, unmarried men are the main perpetrators of crime around the world and are more likely to incur various risks - committing robbery for example - to gain the resources that may attract women, Wright (1994). More than two-thirds of violent and property crimes in China are committed by men aged between 16 and 25 years (Hu, 2006).

\section{Data and Experimental Procedures}

Our data are collected in Shenzhen, a city with a population of 15 million in the southern province of Guangdong which is at the heart of China's manufacturing boom. Approximately $50 \%$ of Shenzhen's population, and $85 \%$ of inmates in the prison in Shenzhen, are ruralurban migrants. We surveyed a random sample of 959 men in a prison in Shenzhen. Of these, 734 prisoners were then randomly chosen to participate in experimental sessions. ${ }^{4}$ We also constructed, surveyed and ran experimental sessions with a representative comparison

\footnotetext{
${ }^{3}$ The Chinese government recently relaxed the policy so that from 1st January 2016 all couples are allowed to have two children.

${ }^{4}$ Fewer prisoners were selected to participate in the experiment for budgetary reasons and because of the limited time we were given to access the inmate subjects. The experiments were conducted in September 2013. We first randomly selected 1200 prisoners to be survey respondents. From these we then randomly selected 1000 to participate in the experimental sessions. We then drop the inmates in our sample that are not rural-urban migrants.
} 
sample of 299 male non-inmate migrant workers in Shenzhen. The sample was constructed using the sampling frame of a representative sample of internal migrants - the 2012 wave of the Rural-Urban Migration in China (RUMiC) survey. The prison takes inmates arrested in both Shenzhen and the neighbouring city of Dongguan so our migrant sample is selected to be representative (in terms of age, education and industry of employment) of the population of male migrants in these two cities, weighted by the relative size of the migrant populations in Dongguan and Shenzhen. ${ }^{5}$

Figures 1 and 2 compare age and education distributions between the RUMiC sample in Shenzhen and Dongguan and that of our sample. The figure shows that the age distributions in the two samples are similar. With regard to education our migrant sample has more college and university degree holders and a smaller proportion of senior high school graduates than those in the RUMiC migrant sample. ${ }^{6}$ We control for education in the empirical work.

\subsection{Survey Questions}

The survey collected a wide array of information including demographic information, migration history (including place of birth), criminal history, and conducted personality tests. A series of questions designed to elicit time preferences were asked at the end of the questionnaire, just prior to the last module which was an IQ test. These ask the respondent to choose between getting a certain amount of money (1000 RMB which was equal to approximately USD160) in one month's time and varying amounts of money in seven months' time. More patient people will choose to defer payment even for a relatively small increase in the amount received, whereas less patient people will only choose to defer payment if the amount received increases by a substantial amount. The choices presented to participants

\footnotetext{
${ }^{5}$ The RUMiC project has been surveying and tracking rural-urban migrants in 15 cities in China, including Shenzhen and Dongguan, since 2008. Dongguan is another large industrial centre with 70 percent of Dongguan's population of 8 million being rural-urban migrants. The sample was recruited by the same survey company which conducted the RUMiC survey. The survey company was given the target age-educationindustry distribution of the sample. They invited RUMiC respondents, and other migrants via the internet, telephone, as well as recruiting directly from the street during November 2013.

${ }^{6}$ The sample is similar to the RUMiC sample in terms of the percentage of the sample with education above and below secondary school level which is the way the sampling frame was defined.
} 
are shown in Figure A1 in the appendix. ${ }^{7}$

The survey questions asked of the migrant sample were identical to those asked of the inmates, except that questions relating to criminal history were omitted.

\subsection{Administrative Data}

In addition to the survey data we have access to and are able to merge all of the prisoners' administrative records onto the survey and experimental data. The administrative data include demographic information such as age and ethnicity, hukou (residency status), and detailed information on criminal histories including types of crimes committed and current and previous sentence lengths.

\subsection{Experiments}

Both the inmate and non-inmate sample were invited to participate in a series of economics experiments. We begin with a description of the procedures in the prison and then describe how some of the procedures necessarily differed outside the prison context.

The randomly selected prisoners were told that they had been selected to participate in an experiment in which there would be the chance to earn some money. ${ }^{8}$ All participants were given the option of not participating, both before and during the experimental sessions, however no one took this option. The experiments were conducted around a week before the survey questions were administered, during the Thursday afternoon and Saturday free time periods in a large conference room. Participants were seated on separate chairs with enough space between them to avoid any communication.

Each prisoner has a prison bank account through which they receive payment for work they do while imprisoned, for example, working in the prison factory. At the conclusion of

\footnotetext{
${ }^{7}$ Prior studies provide evidence in support of unincentivized tasks being able to elicit behavioral preferences, for example, see Gneezy et al. (2015), and questions of the type used here have been widely used to elicit time preferences.

${ }^{8}$ They were not given a specific estimate of how much they might earn.
} 
the games participants received a deposit receipt for the money which was paid into these bank accounts.

The sessions were conducted by one of the authors of this paper (Zhang) who worked with a team of 20 student research assistants from Peking University. The experiments were all conducted in Mandarin with pen and paper as in this context computerization was infeasible. Participants marked their decisions on paper forms. Each participant received a printed copy of the experimental instructions which were also read to the group as a whole. There were opportunities to ask questions and test questions were embedded to enable us to discern whether participants understood the instructions. ${ }^{9}$

Risk Game The risk game is a standard game based on Gneezy and Potters (1997) and involves a series of choices between lotteries. The specific choices faced by the participants are shown in Figure A2 in the appendix. Each decision involves choosing between receiving an amount with certainty (45 Yuan which was approximately US\$7) or a lottery with a $50 \%$ chance of receiving a larger amount and a 50\% chance of receiving nothing. The "winning" amount increases as one works one's way through the choices. Relatively riskloving individuals will prefer the lottery even if they stand to gain only a small amount if they "win", while more risk-averse individuals will switch to choosing the lottery only once the "prize" becomes sufficiently large. ${ }^{10}$ Once all participants had made their choices a participant was asked to draw a ball from a bag in which there were eleven balls numbered from 1 to 11. The chosen ball determined which choice the participants were to be paid for. Then a different participant was asked to roll a dice which determined the outcome for those who had selected a lottery. ${ }^{11}$

\footnotetext{
${ }^{9}$ The vast majority of respondents answered the test questions correctly. Only 17 observations from the inmate sample and 7 observations from the migrant sample failed to answer the test questions correctly. These observations were dropped from the analysis.

${ }^{10}$ Participants were allowed to switch from choosing the certain sum to choosing the lottery at most only once.

${ }^{11}$ The actual payoff method was slightly more complicated than this as each participant played four games in the following order: 1) ultimatum game; 2) risk game; 3) trust game; 4) half of the sample played a dishonesty game based on Mazar et al. (2008) and Friesen and Gangadharan (2013) and half played a compliance game based on (Friesen, 2012). Participants were aware that payments would be made for only
} 
The non-inmate migrants were invited to come to a downtown meeting room. The experiments were conducted in a large meeting room where game participants were seated separately. All payoffs in the risk game were multiplied by 1.5 for the migrant sample. This was done to make the stakes approximately the same value relative to the opportunity cost of time. This is the protocol typically used when conducting games across different cultural settings so as to keep the real value of the stakes as close as possible to constant across groups, Cameron et al. (2009). ${ }^{12}$ Participants were paid in cash at the end of the game. Otherwise, the same protocols were followed as for the inmates.

Census Data We use China's 2000 census to calculate the sex ratios for those currently of prime marriageable age (18 to 27 years of age in 2013) in each individual's prefecture of birth. We call this the "prevailing sex-ratio" and merge it to the inmate and non-inmate data sets. This is similar to the "operational sex ratio" which is commonly used in the biological literature and is defined as the ratio of sexually competing males that are ready to mate to sexually competing females that are ready to mate. ${ }^{13}$ Our total sample of 1,258 rural-urban migrants come from 167 prefectures. The sex ratios range from 1.00 to 1.49 , with a mean of 1.14. ${ }^{14}$ Other prefecture level variables used below are calculated from the 2005 1\% Population Survey (except for prefecture GDP data which is taken from the City

one of these games, which was selected randomly by drawing balls with number 1 to 4 from a bag. The method described above was followed if the risk game was randomly selected for payment.

${ }^{12}$ The stakes for the migrants were set in relation to their opportunity cost of time. In addition to the higher stakes paid, they were paid a show-up fee of $100 \mathrm{RMB}$. The average earnings in the games with the migrant population is $199.67 \mathrm{RMB}$ including the show-up fee. This is $175.2 \%$ (87.5\% if we exclude the show-up fee) of the average daily income for this group. We used lower stakes for the prisoners as prisoners' monthly earnings in jail are very low (less than $10 \%$ of that of the non-prison migrant sample), although they also receive monetary transfers from family members. On average prisoners earn $63.5 \mathrm{RMB}$ from the games which accounts for more than $60 \%$ of their average monthly earnings and $6 \%$ of the average amount held in their prison savings account. Importantly, we have since conducted the same risk games, using the same protocols, with a sample of female prisoners in China. In these games we varied the stakes used. We find that increasing or decreasing the stakes by $50 \%$ does not have affect behaviour in the games (lottery choice) $(\mathrm{p}=0.63)$. Results available on request.

${ }^{13}$ We base our sex-ratio on similar cohorts to the sex-ratio used in Edlund et al. (2013), although theirs is at the provincial level. They use the 16-25 age group for their analysis on the basis that 16 is the age of full criminal responsibility and 25 is the upper age for juvenile crime; and that this is the most crime-prone age group, accounting for more than $70 \%$ of criminal offenders since the mid-1980s.

${ }^{14}$ The prisoners in our sample come from 147 prefectures. The non-inmate respondents come from 105 prefectures. 
Statistical Yearbooks).

\subsection{Summary Statistics}

Table 1 compares summary statistics for the prisoner and non-inmate migrant samples. It shows that on average, the non-inmate migrant sample is of similar age to the inmates. They are, however, somewhat better educated with approximately 3 years more schooling. Their parents are also more educated than the parents of their prisoner counterparts. Non-inmate migrants are 11 percentage points more likely to be married, but have fewer children.

\section{Estimation Strategy}

We start the analysis by examining whether a higher current prevailing sex ratio in one's prefecture of birth is associated with a higher propensity for criminality. ${ }^{15}$ That is, we regress whether the individual is incarcerated or not on the prevailing sex-ratio and a range of individual and prefecture level controls.

We pool migrant and prisoner samples and merge on the prevailing sex ratio in the individual's prefecture of birth. This is a case-control approach - we over-sample those affected by the "rare event" (in our case criminality) and supplement this with a sample from the wider population. This approach has been used widely to study events such as maternal mortality; infant mortality; and criminality. (See for example Ganatra et al. (1998), Blair et al. (1996) and Dobrin (2001).) We follow King and Zeng (2001) and correct for the use of case-control data by estimating logistic regressions when the dependent variable reflects the sampling strategy (i.e. when we are estimating whether the respondent is a prisoner or not). The estimate of the constant is corrected using the ratio of the sample size of prisoners and non-prisoners to their population size. ${ }^{16}$ All regressions presented in this paper control for

\footnotetext{
${ }^{15}$ Our dependent variable reflects incarceration, and not criminality per se. The widely cited crime statistics that show crime increasing in China similarly reflect criminal convictions, rather than the number of crimes actually committed.

${ }^{16}$ We assume a prisoner population in Shenzhen of 86,148 and a migrant population of $3,450,000$. Calculations underlying these assumptions are shown in Section A.1 in the appendix. This empirical strategy
} 
sending province fixed effects and standard errors are clustered at the prefecture level.

\subsection{Exogeneity of Sex Ratios in China}

The most important concern with respect to the validity of our estimation strategy is that prefecture sex-ratios may reflect cultural differences across different prefectures (for example, the extent of son preference) which are also associated with differences in behaviors, such as the propensity to commit a crime. ${ }^{17}$ Edlund et al. (2007) however show that sex-ratios in China are a result of the stringency with which the One Child Policy (OCP) has been implemented. Specifically, they find that the extent of adherence to the OCP is a function of the characteristics of government officials (in particular the extent of central government contacts) at the time of the policy's introduction, and that these characteristics are not serially correlated so sex-ratio at birth is largely unrelated to other contemporaneous outcomes.

If cultural factors or other non-time-varying characteristics of prefectures are important determinants of sex ratios then we would expect to see time dependence in sex ratios. However the correlation in the prefecture sex ratios for cohorts born before the introduction of the OCP (1971 to 1975) and five to ten years after the OCP (1986 to 1995) is almost zero (0.05). Hence it seems it is safe to assume that sex ratios in China are exogenous. Nevertheless, we explore the sensitivity of our results to potential endogeneity below.

\section{Results}

Table 2, Column 1 reports coefficients and marginal effects from regressing the prevailing prefecture of birth sex ratio on the probability of being incarcerated. The coefficient on

relies heavily on the assumption that the errors follow a logistic distribution. Xie and Manski (2010) suggest testing this assumption by estimating and comparing weighted and unweighted logistic regressions. If the errors do follow a logistic distribution, the weighted and unweighted estimates should be similar. Table A1 in the appendix presents the weighted and unweighted results and, as can be seen, they are very similar. We present the unweighted results as our main results in the body of the paper. When estimating regressions with a dependent variable that is other than whether the respondent is the prisoner, we include a dummy for the sampling strata (whether the respondent is a prisoner or not) as suggested by Solon et al. (2015).

${ }^{17}$ Dreze and Khera (2000) find that the sex ratio is strongly positively correlated with murder rates in cross-sectional district level data in India. They suggest that this may be due to endogeneity with more patriarchal districts having stronger preferences for male children and high rates of violence against women. 
the sex ratio is positive and strongly statistically significant. The estimate of the marginal effect suggests that moving from the naturally occurring sex ratio at birth in humans of about 1.07 to our sample mean of 1.14 (114 males for every 100 females) would increase the incarceration rate by about 0.21 percentage points. Given that we estimate that about 2.5 percent of the male migrant population in Shenzhen are incarcerated (see Section A.1), this corresponds to an $8.4 \%$ increase in the probability of being incarcerated for committing a crime.

In column 2 we add additional controls for the individual's age, marital status, number of children, years of schooling, IQ test result, and mother's and father's years of schooling. Column 3 adds prefecture level controls in the regression - the log of prefecture level GDP, the gini coefficient for individual monthly income, the rate of migration out of the prefecture and the share of minority groups in the rural prefecture population. ${ }^{18}$ The only one of these prefecture level variables that is significant is the share of the population from minority ethnicities. It is positive and significant. The inclusion of the household and prefecture controls does not affect the statistical significance of the coefficient on the sex-ratio. The magnitude of the marginal effect increases with the inclusion of the controls to 0.12 . This is a relatively large effect, consistent with a 34 percent increase in crime associated with the increase from the naturally occurring sex-ratio to the sample mean.

Our finding of a positive and significant correlation between the sex ratio faced by individuals from different prefectures of origin and the probability of being incarcerated verifies the findings of Edlund et al. (2013) which found a positive relationship between provincial level sex ratios and crime rates for 30 provinces between 1988 and 2004. That we are able to establish the same relationship between individual propensities to commit criminal acts and sex-ratios from 167 prefectures is of some note.

The other explanatory variables largely have the expected relationship with criminality. Years of schooling is negatively correlated with the probability of being incarcerated, as is

\footnotetext{
${ }^{18}$ The gini coefficient is calculated from data on individuals' monthly incomes in the $20051 \%$ population survey.
} 
mother's educational level. Being married is also negatively associated with being in prison, although prisoners on average have slightly more children than non-inmates. There is not a significant difference in the IQs of inmates and non-inmates. These results are largely consistent with the summary statistics in Table 1.

\subsection{Behavioral Determinants}

So what is driving the relationship between the sex-ratio and crime? As discussed above, growing up in an environment with excess males may affect men's behavioral traits, as has been shown in the literature on animals. Table 3 examines whether two particular behavioral measures which have been hypothesized to be related to criminality in the literature (Becker (1968) and Gottfredson and Hisrchi (1990)) - risk taking and time preferences - are associated with the prevailing sex ratio.

Time Preferences We construct two different indicators of time preferences from the time preference questions. Column 1 uses a continuous measure of patience as the dependent variable. This variable indicates the point at which the respondent switches from choosing to get a payoff in one month's time to getting a payoff in seven months' time. There are eleven questions. Our constructed variable ranges from 0 (most impatient - always chooses to get the money in one month's time) to 11 (most patient -always chooses to get the greater amount in the future). The dependent variable in Column 2 equals one if the individual is the most impatient (always prefers the payment in one month's time instead of seven months' time) and zero otherwise.

Table 3 shows that an excess supply of men is found to be associated with greater impatience. A 10 percentage point increase in the prevailing sex ratio in one's home prefecture is associated with a reduction in the switching point by 0.47 on an 11 point scale, or a 6.3 percentage point increase in the probability that a respondent will always prefer the payment in a month over a payment in seven months' time. 
Risk Preferences Two analogous measures of willingness to take risks are used. Column 3 presents results using a continuous measure indicating the switching point in the risk game (the point at which the participant changes from choosing the sure payment to choosing the gamble) as the dependent variable. We have reverse-coded this variable so that a higher number indicates a greater willingness to take risks. The dependent variable in Column 4 equals one for those who always choose to take the gamble and zero otherwise.

We find that a higher sex-ratio is associated with greater risk-taking. A 10 percentage point increase in the prevailing home prefecture sex ratio is associated with a 4.7 percent increase in the probability that a respondent chooses always to take the riskiest option (significant at the $10 \%$ level).

Personality Traits We also collected information on the Big 5 personality traits and examine whether they are associated with the sex ratio. ${ }^{19}$ Table 4 presents the results. Extroversion, conscientiousness, openness and agreeableness are not statistically significantly associated with the prevailing sex ratio. The sex-ratio is associated with an increased neuroticism score. A 10 percentage point increase in the sex ratio is associated with about a 0.03 increase in the neuroticism score (which has a mean of 3.07 and a standard deviation of 0.37). This result proves not to be robust to the inclusion of additional prefecture controls in the robustness tests below.

Having found reasonably large impacts of the sex-ratio on behavioral preferences, we now examine whether these preferences are associated with a greater risk of criminality. Column 1 in Table 5 replicates the result in Table 2 that the prevailing sex-ratio is significantly associated with a greater probability of criminality. Column 2 shows the results of regressing whether one is a prisoner or not on measures of risk and time preferences. Being in the upper tail of the distributions of impatience and risk-taking is associated with a greater probability

\footnotetext{
${ }^{19}$ The Big 5 personality traits measure five broad dimensions of personality that have been found to be consistent non-overlapping measures of personalities with wide applicability across cultures. The five dimensions are openness to experience, conscientiousness, extroversion, agreeableness and neuroticism.
} 
of criminality. The effects of the behavioral impacts are strongly significant and positive.

Column 3 adds the prevailing sex-ratio to the regression. Its coefficient is largely unaffected by the inclusion of the behavioral parameters and remains strongly statistically significant, as do the coefficients on the behavioral parameters. Column 4 adds the household and prefecture controls that were included in Table 2. The inclusion of these controls reduces the significance of the time preference variable. Being in the riskiest category however remains strongly significant and becomes slightly larger in magnitude. The magnitude of the effect is relatively large. Being in the riskiest group is associated with about a 1 percentage point $(40 \%)$ increase in the probability of being incarcerated. ${ }^{20}$

The final column in Table 5 adds controls for the Big 5 personality traits - neuroticism, openness, agreeableness, extroversion and conscientiousness - and finds that they are strongly significant determinants of crime. Consistent with the psychology literature, neuroticism is strongly and positively related to criminality (Egan, 2009). Our results that conscientiousness and openness are negatively associated with criminality are also largely consistent with expectations. We also find that in the Chinese context extroversion is negatively associated with crime. ${ }^{21}$ Importantly, the sex-ratio remains strongly significant when the behavioral and personality traits are included in the criminality regressions, suggesting that there are mechanisms in addition to the behavioral ones identified above that drive the relationship between criminality and the sex-ratio.

A possible concern with these results is that being in prison may affect preferences and so we may be picking up the effect of being incarcerated on preferences rather than the effect of preferences on criminality. This is less of a concern for the Big-5 personality traits which are thought to be relatively stable over time but is a greater concern for the questions on time preferences and risk attitudes.

\footnotetext{
${ }^{20}$ The magnitude of the coefficient on the indicator of being in the most impatient group suggests a 0.4 ppt $(16 \%)$ in the probability of being an inmate but is statistically insignificant.

${ }^{21}$ The psychology literature has found that psychopathy in males is associated with lower agreeableness, conscientiousness, and greater neuroticism (Egan, 2009). Low openness has been found to have some connection with crime but less consistently than the other traits, Wiebe (2004).
} 
If incarceration does affect behavior then one would expect that the length of time spent in prison would be associated with behavioral differences. We test this by adding the time spent in prison as an additional control variable in the regressions, while also controlling for total sentence length. Table A2 presents these results and shows that the coefficients on both of these variables are statistically insignificant in all estimations. Including these variables does not change the estimated effect of the sex-ratio. ${ }^{22}$

Although we find quite large effects of the sex-ratio on behavioral preferences and of behavioral preferences on criminality, when we put these two results together - the effect of the sex-ratio on risk and time preferences and the impact of these preferences on criminality we find that a 10 percentage point increase in the sex ratio increases the probability of being incarcerated via increased risk-taking by 0.05 percentage points $(2.0 \%)$ and via impatience by 0.025 percentage points $(0.8 \%) .{ }^{23}$ Hence, a total of 0.075 percentage points $(3 \%)$ increase via behavioral channels. This accounts for only about $6.3 \%$ of the total effect of the sex-ratio on incarceration. ${ }^{24}$

\subsection{Examining Marriage Market Mechanisms}

So it appears that although the sex ratio does have an impact on underlying behavioral parameters and these in turn affect criminality, the sex ratio continues to have a strong effect on criminality, independent of the behavioral effect. The pressure the high sex ratio places on men looking to find a wife has been hypothesized in the literature to be an important driver of the relationship between the sex ratio and criminality. There is pressure on men to make themselves more financially attractive in order to find a mate in a world in which there

\footnotetext{
${ }^{22}$ Another test we conduct is to examine whether the sex ratio determines the behavioral parameters within the prisoner sample. The sex ratio remains strongly significant in unreported results estimated off just the prison sample.

${ }^{23}$ These figures are calculated using the marginal effects of the sex-ratio on risk and time preferences in columns 2 and 4 of Table 3 and the marginal effects of risk-taking and time preferences on criminality in column 5 in Table 5 . For risk-taking $-(0.1 * 0.47)^{*} 0.01=0.047$ ppts; for impatience $-\left(0.1^{*} 0.63\right)^{*} 0.004=$ 0.025 ppts.

${ }^{24}$ From Table 2 Column 3, the total effect of a ten percentage point increase in the sex-ratio on criminality is 1.2 percentage points. $0.075 / 1.2=6.3 \%$.
} 
are many more men than women. This hypothesis has however not been directly tested.

If the prevailing sex ratio is capturing what people perceive to be marriage market pressures, then its effect should be strongest for unmarried men. To examine this mechanisms we interact the prevailing sex ratio with whether the respondent is married or not. The existing literature, in particular, the social biology literature, predominantly relates individuals' behaviors and criminal activities to their own reproductive needs. However, in a society where the traditional family structure is still highly valued, individuals may take into account their offsprings' reproductive needs. The sex-ratio may thus also exert a greater pressure upon men who have children (particularly sons who carry on the family name) than those who don't. ${ }^{25}$ To investigate this avenue, we also interact the prevailing sex ratio with a variable that indicates whether the respondent has children, and allow this to vary with the presence of sons (by interacting the sex-ratio and a variable defined to equal one if he respondent only has daughters and is unlikely to have any more children, as indicated by the youngest child being more than 10 years of age, and zero otherwise).

Table 6 reports the results. Column (1) shows that for unmarried men the prevailing sex ratio is strongly positively associated with the probability of being incarcerated. A 10 percentage point increase in the prevailing sex ratio is associated with almost a 1.8 percentage point increase in the probability of incarceration. This effect is largely offset for married men and becomes insignificant $(\mathrm{p}=0.38)$. Column $(2)$ explores the effects of having children. It shows that men with children are slightly more likely to be in prison than men without children. This impact does not vary with the sex of the child.

In summary, the sex ratio affects criminality a little through behavioral impacts but most of the impact operates via the direct impact on unmarried men through the marriage market.

\footnotetext{
${ }^{25}$ In modern China, although many middle income families have adopted western values, traditional Confucian teachings are still strong, particularly in rural areas. In Confucian thought, filial piety is considered the first virtue. In discussing filial piety one of the most renown Chinese philosophers, Mencius, finds that there are three ways of being unfilial, and to have no posterity (no descendants) is the greatest of them (Lee (2004), page 142). Thus, having male descendants to carry on the family name is of prime importance.
} 


\subsection{What Types of Crime?}

We now examine whether a high sex ratio is related to particular types of crime. The discussion above would suggest that it is related to economic crime, as unmarried men try to make themselves more financially attractive in the marriage market. The socio-biological and criminology literature however suggests that high sex ratios may result in greater aggression towards females, and so we might expect a greater increase in violent crime.

The prison administrative data provide detailed descriptions of crime types. We have coded them into two, not mutually exclusive, categories: violent crime (including robbery, sexual offences, and violence); and economic crime (robbery, burglary, drug dealing, and other economic crime such as providing gambling venues, illegal business dealings, etc.). We also examine sexual crime separately so as to be able to examine whether the sex-ratio has any association with sexual assault. We report marginal effects from logits on the prison sample with violent crime, sexual offences or economic crime as the dependent variable.

We find that economic crime is positively associated with the sex-ratio and that again this relationship is being driven by unmarried men. The prevailing sex-ratio is not associated with violent or sexual crimes (see Table 7).

\subsection{Robustness Checks}

Instrumental Variables Results We have argued above that the sex-ratio in China is exogenous because it reflects the implementation of the one child policy. Edlund et al. (2007) present empirical evidence in support of this, as do we above. Nevertheless, to dispel any remaining concerns about endogeneity, in this section we instrument for the prevailing sexratio. We construct an instrument that reflects the severity of the implementation of the policy and interact this with the inverse of the ethnic minority share of the rural prefecture population (as ethnic minorities are not subject to the policy). ${ }^{26}$ This instrument is a

\footnotetext{
${ }^{26}$ Our measure of the strictness with which the policy is implemented is the quantitative indicator of "policy fertility" developed by Baochang et al. (2007). This indicator is the average number of children per women who would be born in the prefecture if childbearing rigorously followed the prescribed fertility policy.
} 
statistically significant predictor of prefecture sex-ratios, and strongly so when household and prefecture controls are included in the model (Column 2). The results in Column 1 of Table 8 show that the coefficient on the prevailing sex-ratio remains positive and statistically significant when instrumented. The coefficient increases in magnitude (from 0.12 in Column 3 in Table 2 to 0.18). Note that the IV and OLS coefficients are not statistically significantly different from one another. When we include the individual and prefecture controls the coefficient on the sex ratio remains large and positive. Its statistical significance drops so that it just falls under the $10 \%$ significance level $(\mathrm{p}=0.12)$.

To further dispel concerns that the sex ratio may be proxying for unobservable characteristics of the prefectures we re-estimated all specifications including an additional array of prefecture-level controls. We include controls for the proportion of the prefecture's rural population with educational attainment of at least high school level; the proportion who are in the labour force; the unemployment rate; the proportion who have rural residency status; average log annual income; and average real gdp per capita growth between 2002 and 2012. The only result that was affected by the inclusion of these controls was that showing a positive relationship between neuroticism and the prevailing sex ratio, with the coefficient on the sex ratio becoming smaller and statistically insignificant $(p=0.24)$. Results available on request.

\section{Conclusions}

To conclude, we find that the prevailing home prefecture sex-ratio is positively associated with the propensity to commit crimes. Some of this relationship is accounted for by the finding that a high sex ratio is associated with greater risk-taking and impatience. The behavioral component is however relatively small, explaining $6.3 \%$ of the impact of the sexratio. The direct pressure on men to find a partner in the marriage market is the primary driver of the increases in crime. Men turn to criminal activity in response to the greater competition in finding a mate and the need to appear more financially attractive. These 
marriage market pressures result in a higher propensity to commit financially rewarding crimes.

Recently, in response to the skewing of sex-ratios, the rapid aging of the population, and reports of behavioral problems among the single child generation, the Chinese government relaxed the One Child Policy and now allows all couples to have two children. It remains unclear, however, to what extent this change will ultimately affect sex-ratios, and hence what are the implications for crime. Some researchers have predicted little change in fertility behavior (Cai, 2010). Even if the new policy does result in a more balanced sex-ratio, it will take at least a generation before the ratio between men and women in the marriage market approaches parity. Hence, the current marriage market pressures are likely to be sustained and possibly worsen in the short term, with the concomitant incentives to engage in crime. 


\section{References}

Baochang, Gu, Wang Feng, Guo Zhigang, and Zhang Erli, "China's Local and National Fertility Policies at the End of the Twentieth Century," Population and Development Review, Mar 2007, 33 (1), 129-147.

Barber, Nigel, "The Sex Ratio and Female Marital Opportunity as Historical Predictors of Violent Crime in England. Scotland, and the United States," Cross-Cultural Research, Nov 2003, 37 (4), 373-392.

Becker, Gary S., "Crime and Punishmet: An Economic Analysis," Journal of Political Economy, 1968, 76 (2), 169-217.

Blair, Peter S, Peter J Fleming, David Bensley, Iain Smith, Chris Bacon, Elizabeth Taylor, Jem Berry, Jean Golding, and John Tripp, "Smoking and the sudden infant death syndrome: results from 1993-5 case-control study for confidential inquiry into stillbirths and deaths in infancy," British Medical Journal, 1996, 313.

Cai, Yong, "China's Below-Replacement Fertility: Government Policy or Socioeconomic Development?," Population and Development Review, Oct 2010, 36 (3), 419-440.

Cameron, Lisa, Ananish Chaudhuri, Nisvan Erkal, and Lata Gangadharan, "Do Attitudes Towards Corruption Differ Across Cultures? Experimental Evidence from Australia, India, Indonesia and Singapore," Journal of Public Economics, 2009, 93, 843-851.

Dobrin, Adam, "The Risk of Offending on Homocide Victimization: A Case Control Study," Criminology and Penology, 2001, 38 (2), 154-73.

Dreze, Jean and Reetika Khera, "Crime, gender, and Society in India: Insights from Homicide Data," Population and Development Review, 2000, 26 (2).

Edlund, L., H. Li, J. Yi, and J. Zhang, "Sex Ratios and Crime: Evidence from China," IZA Discussion Paper, 2007, (3214).

_ , _ , , and _ , "Sex Ratios and Crime: Evidence from China," Review of Economics and Statistics, Dec 2013, 95 (5), 1520-1534.

Egan, V., Can personality change?, Chichester: Wiley and Sons, Ltd.,

Friesen, Lana, "Certainty of Punishment versus Severity of Punishment: An Experimental Investigation," Southern Economic Journal, Oct 2012, 79 (2), 399-421.

- and Lata Gangadharan, "Designing self-reporting regimes to encourage truth telling: An experimental study," Journal of Economic Behavior and Organisation, Oct 2013, 94, 90-102.

Gan, Li, Yin Zhcnao, Jia Nan, Xi Shu, Ma Shuang, and Zheng Lu, Data you need to know about China: Research Report of China Household Finance Survey, New York: Springer, 2013.

Ganatra, B.R., K.J. Coyaji, and V.N. Rao, "Too far, too little, too late: a community-based case-control study of maternal mortality in rural west Maharashtra, India," Bulletin of the World Health Organisation, 1998, 76 (6), 591-598. 
Gneezy, Uri, Alex Imas, and John List, "Estimating Individual Ambiguity Aversion: A Simple Approach," NBER Working Paper, Feb 2015, 20982, 1-23.

- and Jan Potters, "An Experiment on Risk Taking and Evaluation Periods," Quarterly Journal of Economics, May 1997, pp. 631-645.

Gottfredson, Michael R. and Travis Hisrchi, A General Theory of Crime, Stanford: Stanford University Press, 1990.

Hu, Lianhe, Zhuan Xing Yu Fan Zui: Zhong Guo Zhuan Xing Qi Fan Zui Wen Ti De Shi Zheng Yan Jiu [Transition and Crime: An Empirical Analysis of Crime during Chinas Economic Transition], Beijing: Central Communist Party School Press, 2006.

Hudson, Valerie and Andrea M. Den Boer, "A Surplus of Men, a Deficit of Peace: Security and Sex Ratios in Asias Largest States," International Security, 2002, 26 (4), 5-38.

King, Gary and Langche Zeng, "Logistic Regression in Rare Events Data," Political Analysis, 2001, 9 (2), 137-163.

Le Galliard, Jean-Francois, Patrick S. Fitze, Regis Ferriere, and Jean Clobert, "Sex ratio bias, male aggression, and population collapse in lizards," Proceedings of National Academy of Science, Dec 2005, 102 (50), 18231-18236.

Lee, C.Y., Filial Piety in Chinese Thought and History, Routledge, 2004.

Liu, Jianhong, "Crime Patterns During the Market Transition In China," The British Journal of Criminology, 2005, 45, 613-633.

Mazar, N., O. Amir, and D. Ariely, "The dishonesty of honest people: a theory of self-concept maintenance," Journal of Marketing Research, 2008, 45, 633-644.

Michler, Stephanie, Marion Nicolaus, Richard Ubels, Marco van der Velde, Christian Botha, and Joost Tinbergen ans Jan Komdeur, "Do Sex-Specific Densities affect local survival of free-ranging great tits," Behavioral Ecology, 2011, 22, 869-879.

NBS, 2013 National Economic and Social Development Statistical Report, Beijing: China Statistics Press, 2014.

Solon, Gary, Steven J. Haider, and Jeffrey M. Wooldridge, "What are we weighting for?," Journal of Human Resources, Spring 2015, 50 (2), 301-316.

Wiebe, Richard P., "Delinquent Behavior and the Five-Factor Model: Hiding in the Adaptive Landscape?," Individual Differences Research, 2004, 2 (1), 38-52.

Wilson, Margo and Martin Daly, "Competitiveness, Risk Taking and Violence: The Young Male Syndrome," Ethology and Sociobiology, 1985, 6, 59-73.

Wright, Robert, The Moral Animal. Why we are the way we are. The New Science of Evolutionary Psychology, New Yorkj: Vintage, 1994.

Xie, Yu and Charles F. Manski, "The logit model, the probit model, and response-based samples," University of Wisconsin-Madison, Center for Demography and Ecology, 2010, 88-4. 
Zhang, J., "Research into six important relationships which affect significant increase in Chinas crime rate," Chinese University of Public Security Report (in Chinese), 2011, 5.

Zhang, Y., S. Q. Liu, and L. Liu, "Rural-urban income difference, unemployment of migrants, and increase in Chinas crime rate," Economic Research (In Chinese), 2011.

Zhu, Wei Xing, Li Lu, and Therese Hesketh, "Chinas Excess Males, Sex Selective Abortion, and One Child Policy: Analysis of Data from 2005 National Intercensus Survey," British Medical Journal, 2009, 338. 
Table 1: Summary Statistics

\begin{tabular}{|c|c|c|c|c|c|}
\hline Variable & $\begin{array}{c}\text { Mean } \\
\text { All }\end{array}$ & $\begin{array}{c}\text { Mean } \\
\text { Inmates }\end{array}$ & $\begin{array}{c}\text { Mean } \\
\text { Migrants }\end{array}$ & Difference & \\
\hline \multicolumn{6}{|l|}{ Individual Variables: } \\
\hline age & 29.70 & 29.85 & 29.32 & -0.53 & \\
\hline years of education & 8.84 & 7.86 & 11.22 & 3.36 & $* * *$ \\
\hline IQ test score & 6.23 & 5.93 & 6.96 & 1.03 & $* * *$ \\
\hline Married $(0 / 1)$ & 0.35 & 0.32 & 0.43 & 0.11 & $* * *$ \\
\hline Number of children & 0.66 & 0.69 & 0.58 & -0.12 & $* *$ \\
\hline Father's years of education & 7.15 & 6.78 & 8.03 & 1.25 & $* * *$ \\
\hline Mother's years of education & 5.39 & 4.82 & 6.79 & 1.97 & $* * *$ \\
\hline \multicolumn{6}{|l|}{ Prefecture Variables: } \\
\hline Prevailing sex ratio & 1.14 & 1.15 & 1.12 & -0.03 & $* * *$ \\
\hline Log of GDP/capita & 9.40 & 9.37 & 9.46 & 0.09 & $* * *$ \\
\hline Gini coefficient & 0.35 & 0.35 & 0.35 & -0.01 & $*$ \\
\hline Out-migration rate & 2.05 & 1.85 & 2.52 & 0.66 & $* * *$ \\
\hline Ethnic minority population share & 0.10 & 0.12 & 0.04 & -0.08 & $* * *$ \\
\hline \multicolumn{6}{|l|}{ Behavioral Variables: } \\
\hline Patience & 5.32 & 5.26 & 5.46 & 0.20 & . \\
\hline Least patient & 0.29 & 0.31 & 0.22 & -0.09 & $* * *$ \\
\hline Risk-loving & 9.56 & 9.94 & 8.65 & -1.29 & $* * *$ \\
\hline Riskiest & 0.21 & 0.24 & 0.13 & -0.10 & $* * *$ \\
\hline \multicolumn{6}{|l|}{ Big 5 Personality Traits: } \\
\hline Neuroticism & 3.07 & 3.10 & 2.99 & -0.11 & $* * *$ \\
\hline Openness & 3.25 & 3.19 & 3.42 & 0.23 & $* * *$ \\
\hline Agreeableness & 3.05 & 3.03 & 3.09 & 0.06 & $* * *$ \\
\hline Extroversion & 3.16 & 3.12 & 3.26 & 0.14 & $* * *$ \\
\hline Conscientiousness & 3.20 & 3.16 & 3.28 & 0.12 & $* * *$ \\
\hline $\mathrm{N}$ & 1006 & 712 & 294 & & \\
\hline
\end{tabular}

Notes: $* * *$ indicates significance at $1 \%$ level, $* *$ at $5 \%$ level, ${ }^{*}$ at $10 \%$ level. 
Table 2: Is the Sex Ratio a Determinant of Criminal Activity?

\begin{tabular}{|c|c|c|c|c|c|c|}
\hline & \multicolumn{6}{|c|}{ Dependent Variable $=$ Prisoner $(0 / 1)$} \\
\hline & \multicolumn{2}{|c|}{ (1) } & \multicolumn{2}{|c|}{$(2)$} & \multicolumn{2}{|c|}{ (3) } \\
\hline & coeffs & $\begin{array}{l}\text { marginal } \\
\text { effects }\end{array}$ & coeffs & $\begin{array}{l}\text { marginal } \\
\text { effects }\end{array}$ & coeffs & $\begin{array}{c}\text { marginal } \\
\text { effects }\end{array}$ \\
\hline Prevailing sex ratio & $\begin{array}{c}6.27 \\
(2.25)^{* * *}\end{array}$ & $\begin{array}{c}.03 \\
(.01)^{* * *}\end{array}$ & $\begin{array}{c}6.13 \\
(2.99)^{* *}\end{array}$ & $\begin{array}{c}.08 \\
(.04)^{* *}\end{array}$ & $\begin{array}{c}8.42 \\
(3.36)^{* *}\end{array}$ & $(.12)$ \\
\hline Age & & & $\begin{array}{l}.003 \\
(.02)\end{array}$ & $\begin{array}{l}.000 \\
(.0002)\end{array}$ & $\begin{array}{l}.001 \\
(.02)\end{array}$ & $\begin{array}{l}.000 \\
(.0003)\end{array}$ \\
\hline Years of education & & & $(.05)^{-.5 * *}$ & $(.002)^{* * *}$ & $(.05)^{-.51}$ & $(.002)^{* * *}$ \\
\hline IQ test score & & & $\begin{array}{l}.01 \\
(.04)\end{array}$ & $\begin{array}{l}.0001 \\
(.0005)\end{array}$ & $\begin{array}{l}.02 \\
(.03)\end{array}$ & $\begin{array}{l}.0003 \\
(.0005)\end{array}$ \\
\hline Married & & & $\begin{array}{l}-1.24 \\
(.28)^{* * *}\end{array}$ & $(.006)^{-.02}$ & $\begin{array}{l}-1.33 \\
(.28)^{* * *}\end{array}$ & $(.006)^{-.02}$ \\
\hline Number of children & & & $(.18)^{* * *}$ & $(.003)^{* *}$ & $(.18)^{6 * * *}$ & $\begin{array}{c}.009 \\
(.003)^{* * *}\end{array}$ \\
\hline Father's years of education & & & $\begin{array}{l}-.005 \\
(.03)\end{array}$ & $\begin{array}{l}-.0001 \\
(.0003)\end{array}$ & $\begin{array}{l}-.006 \\
(.03)\end{array}$ & $\begin{array}{l}-.0001 \\
(.0004)\end{array}$ \\
\hline Mother's years of education & & & $(.03)^{* *}$ & $\begin{array}{l}-.0009 \\
(.0004)^{* *}\end{array}$ & $(. .03)^{* *}$ & $(.0005)^{* *}$ \\
\hline Log of per capita GDP & & & & & $\begin{array}{l}.46 \\
(.42)\end{array}$ & $\begin{array}{l}.007 \\
(.006)\end{array}$ \\
\hline Gini coefficient & & & & & $\begin{array}{c}3.01 \\
(2.98)\end{array}$ & $\begin{array}{l}.04 \\
(.05)\end{array}$ \\
\hline Out-migration rate & & & & & $\begin{array}{l}-.03 \\
(.03)\end{array}$ & $\begin{array}{l}-.0005 \\
(.0004)\end{array}$ \\
\hline Minority population share & & & & & $\begin{array}{c}3.21 \\
(.93)^{* * *}\end{array}$ & $(.01)^{* * *}$ \\
\hline $\mathrm{N}$ & & & & & & \\
\hline Pseudo R-squared & & & & & & 2 \\
\hline
\end{tabular}

Notes: We report coefficients and marginal effects from logistic regressions. The calculation of the marginal effects is corrected for choice-based sampling using the method of prior correction, see King and Zeng (2001). All specifications include provincial fixed effects. Standard errors are clustered by prefecture. ${ }^{* * *}$ indicates significance at $1 \%$ level, ${ }^{* *}$ at $5 \%$ level, ${ }^{*}$ at $10 \%$ level. 


\begin{tabular}{|c|c|c|c|c|}
\hline \multirow[b]{2}{*}{ Dependent Variables: } & \multicolumn{2}{|c|}{ Patience } & \multicolumn{2}{|c|}{ Risk-Loving } \\
\hline & $\begin{array}{c}\text { Continuous } \\
(1)\end{array}$ & $\begin{array}{c}\text { Least Patient }(0 / 1) \\
(2)\end{array}$ & $\begin{array}{c}\text { Continuous } \\
(3)\end{array}$ & $\begin{array}{c}\text { Riskiest }(0 / 1) \\
(4)\end{array}$ \\
\hline \multicolumn{5}{|l|}{ Panel A: Without Controls } \\
\hline$\overline{\text { Prevailing sex ratio }}$ & $\begin{array}{l}-2.25 \\
(2.12)\end{array}$ & $\begin{array}{l}.35 \\
(.25)\end{array}$ & $\begin{array}{l}1.76 \\
(1.42)\end{array}$ & $\begin{array}{l}.32 \\
(.25)\end{array}$ \\
\hline $\mathrm{N}$ & 1006 & 1006 & 1006 & 1006 \\
\hline R-squared & .009 & .02 & .05 & .04 \\
\hline \multicolumn{5}{|l|}{ Panel B: With Controls } \\
\hline Prevailing sex ratio & $(2.14)^{-4 *}$ & $(.25)^{* *}$ & $\begin{array}{l}2.18 \\
(1.66)\end{array}$ & $(.478)^{*}$ \\
\hline Age & $\begin{array}{l}.03 \\
. .03)\end{array}$ & $\begin{array}{l}-.003 \\
(.003)\end{array}$ & $\begin{array}{l}.02 \\
(.02)\end{array}$ & $\begin{array}{l}-.003 \\
(.003)\end{array}$ \\
\hline Years of Education & $\begin{array}{l}-.07 \\
(.05)\end{array}$ & $\begin{array}{l}-.003 \\
(.006)\end{array}$ & $\begin{array}{l}-.09 \\
(.04)^{* *}\end{array}$ & $\begin{array}{l}-.004 \\
(.006)\end{array}$ \\
\hline IQ test score & $\begin{array}{l}-.09 \\
(.06)\end{array}$ & 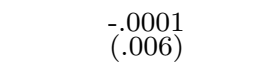 & $(.05)^{-.12}$ & $\begin{array}{l}-.008 \\
(.006)\end{array}$ \\
\hline Married & $\begin{array}{l}.28 \\
(.38)\end{array}$ & $\begin{array}{l}-.003 \\
(.04)\end{array}$ & $\begin{array}{l}-.3 \\
(.26)\end{array}$ & $(.06)$ \\
\hline Number of children & $\begin{array}{l}-.14 \\
(.21)\end{array}$ & $\begin{array}{l}.005 \\
(.02)\end{array}$ & $\begin{array}{l}.08 \\
(.16)\end{array}$ & $\begin{array}{l}-.02 \\
(.02)\end{array}$ \\
\hline Father's years of education & $\begin{array}{l}-.04 \\
(.04)\end{array}$ & $\begin{array}{l}-.003 \\
(.005)\end{array}$ & $\begin{array}{l}-.04 \\
(.03)\end{array}$ & $\begin{array}{l}-.004 \\
(.004)\end{array}$ \\
\hline Mother's years of education & $\begin{array}{l}.03 \\
(.04)\end{array}$ & $\begin{array}{l}.004 \\
(.005)\end{array}$ & $\begin{array}{l}.01 \\
(.03)\end{array}$ & $\begin{array}{l}.003 \\
(.004)\end{array}$ \\
\hline Log of per capital GDP & $\begin{array}{l}-.56 \\
(.29)^{*}\end{array}$ & $(.06)^{*}$ & $\begin{array}{l}.15 \\
(.26)\end{array}$ & $(.05)^{*}$ \\
\hline Gini coefficient & $\begin{array}{l}-3.7 \\
(2.77)\end{array}$ & $\begin{array}{l}.12 \\
(.32)\end{array}$ & $\begin{array}{c}.4 \\
(2.07)\end{array}$ & $\begin{array}{l}.23 \\
(.3)\end{array}$ \\
\hline Out-migration rate & $\begin{array}{l}.009 \\
(.03)\end{array}$ & $\begin{array}{r}-.0008 \\
-(.003)\end{array}$ & $\begin{array}{l}.008 \\
(.02)\end{array}$ & $\begin{array}{l}-.003 \\
(.002)\end{array}$ \\
\hline Minority population share & $\begin{array}{l}-1.65 \\
(.85)^{*}\end{array}$ & $(.26$ (1) & $\begin{array}{l}.35 \\
(.56)\end{array}$ & $\begin{array}{l}.14 \\
(.09)\end{array}$ \\
\hline $\mathrm{N}$ & 1006 & 1006 & 1006 & 1006 \\
\hline R-squared & .03 & .03 & .07 & .05 \\
\hline
\end{tabular}

Notes: All specifications also control for prisoner as a correction for choice-based sampling. The inclusion of the variable on which the sample was stratified ensures that the sampling is independent of the dependent variable conditional on the explanatory variables and hence the coefficient estimates are consistent, see Solon et al. (2015). The variable is significant in some specifications but its inclusion does not affect the magnitude of the other coefficients. All specifications include provincial fixed effects. Standard errors are clustered by prefecture. ***indicates significance at $1 \%$ level, ** at $5 \%$ level, * at $10 \%$ level. 
Table 4: Is the Sex Ratio a Determinant of Personality Traits?

\begin{tabular}{|c|c|c|c|c|c|}
\hline Dependent variable: & Neuroticism & Openness & Agreeableness & Extroversion & Conscientiousness \\
\hline Prevailing sex ratio & $\begin{array}{l}.28 \\
(.17)^{*}\end{array}$ & $\begin{array}{l}.11 \\
(.19)\end{array}$ & $\begin{array}{l}.17 \\
(.17)\end{array}$ & $\begin{array}{l}.14 \\
(.2)\end{array}$ & $\begin{array}{l}-.05 \\
(.2)\end{array}$ \\
\hline Age & $\begin{array}{l}.003 \\
(.002)\end{array}$ & $(.002)^{* * *}$ & $(.003) *$ & $\begin{array}{l}.003 \\
(.002)\end{array}$ & $\begin{array}{l}.003 \\
(.002)\end{array}$ \\
\hline Years of education & $\begin{array}{l}.002 \\
(.004)\end{array}$ & $(.009)^{*}$ & $\begin{array}{l}.001 \\
(.004)\end{array}$ & $\begin{array}{l}-.002 \\
(.005)\end{array}$ & $\begin{array}{l}.003 \\
(.004)\end{array}$ \\
\hline IQ test score & $\begin{array}{l}-.0007 \\
(.005)\end{array}$ & $\begin{array}{l}.004 \\
(.005)\end{array}$ & $\begin{array}{l}.003 \\
(.004)\end{array}$ & $\begin{array}{l}.0007 \\
(.005)\end{array}$ & $\begin{array}{l}.003 \\
(.005)\end{array}$ \\
\hline Married & $\begin{array}{l}-.04 \\
(.03)\end{array}$ & $\begin{array}{l}.05 \\
(.03)^{*}\end{array}$ & $\begin{array}{l}.006 \\
(.03)\end{array}$ & $\begin{array}{l}-.01 \\
(.03)\end{array}$ & $\begin{array}{l}.003 \\
(.03)\end{array}$ \\
\hline Number of children & $\begin{array}{l}.008 \\
(.02)\end{array}$ & $\begin{array}{l}.001 \\
(.02)\end{array}$ & $\begin{array}{l}.004 \\
(.02)\end{array}$ & $\begin{array}{l}.01 \\
(.02)\end{array}$ & $\begin{array}{l}.02 \\
(.01)\end{array}$ \\
\hline Father's years of education & $\begin{array}{l}-.004 \\
(.003)\end{array}$ & $\begin{array}{l}.004 \\
(.004)\end{array}$ & $\begin{array}{l}.001 \\
(.003)\end{array}$ & $\begin{array}{l}.001 \\
(.004)\end{array}$ & $\begin{array}{l}.0002 \\
(.003)\end{array}$ \\
\hline Mother's years of education & $\begin{array}{l}.0002 \\
(.004)\end{array}$ & $\begin{array}{l}.002 \\
(.004)\end{array}$ & $\begin{array}{l}.002 \\
(.003)\end{array}$ & $\begin{array}{l}.0003 \\
(.004)\end{array}$ & $\begin{array}{l}-.002 \\
(.003)\end{array}$ \\
\hline log of per capital GDP & $\begin{array}{l}.03 \\
(.03)\end{array}$ & $\begin{array}{l}-.002 \\
(.03)\end{array}$ & $\begin{array}{l}.03 \\
(.02)\end{array}$ & $(.05)^{*}$ & $\begin{array}{l}.03 \\
(.03)\end{array}$ \\
\hline Gini coefficient & $\begin{array}{l}.09 \\
(.22)\end{array}$ & $\begin{array}{l}.36 \\
(.24)\end{array}$ & $\begin{array}{l}.13 \\
(.22)\end{array}$ & $\begin{array}{l}.42 \\
(.3)\end{array}$ & $\begin{array}{l}.16 \\
(.24)\end{array}$ \\
\hline Out-migration rate & $\begin{array}{l}.001 \\
(.002)\end{array}$ & $\begin{array}{l}.001 \\
(.003)\end{array}$ & $\begin{array}{l}.001 \\
(.002)\end{array}$ & $\begin{array}{l}.003 \\
(.002)\end{array}$ & $\begin{array}{l}.002 \\
(.003)\end{array}$ \\
\hline Minority population share & $\begin{array}{l}.01 \\
(.06)\end{array}$ & $\begin{array}{l}.02 \\
(.08)\end{array}$ & $(.05)^{*}$ & $\begin{array}{l}-.04 \\
(.07)\end{array}$ & $\begin{array}{l}-.04 \\
(.06)\end{array}$ \\
\hline $\mathrm{N}$ & 1006 & 1006 & 1006 & 1006 & 1006 \\
\hline R-squared & .04 & .1 & .03 & .05 & .05 \\
\hline
\end{tabular}

Notes: We report coefficients from OLS estimation. The controls used are those used in Table 3. All specifications include provincial fixed effects. Standard errors are clustered by prefecture. The inclusion of the variable on which the sample was stratified ensures that the sampling is independent of the dependent variable conditional on the explanatory variables and hence the coefficient estimates are consistent, see Solon, Haider and Wooldridge(2013). The variable is significant in some specifications but its inclusion does not affect the magnitude of the other coefficients. $* * *$ indicates significance at $1 \%$ level, $* *$ at $5 \%$ level, $*$ at $10 \%$ level. 


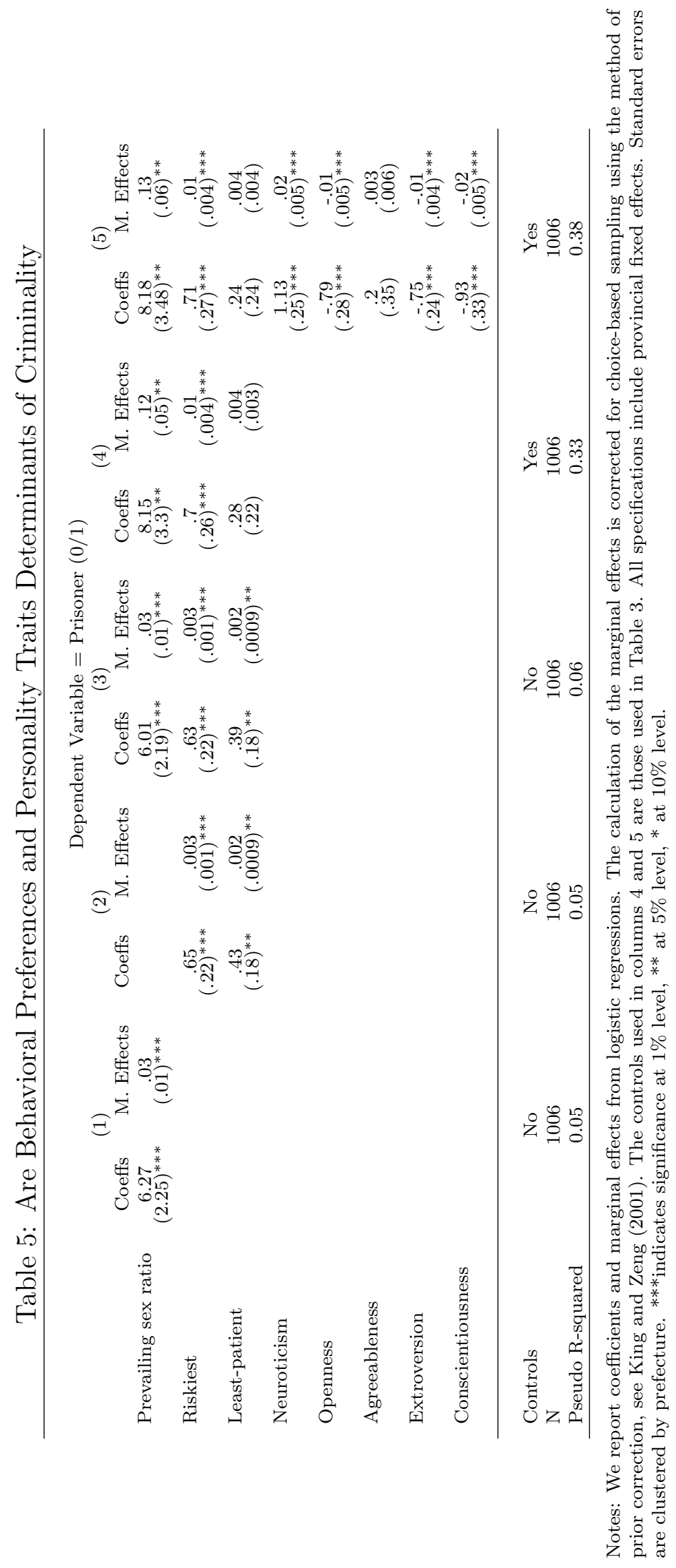


Table 6: Mechanisms via which the Sex Ratio Affects Criminality

Dependent Variable $=$ Prisoner $(0 / 1)$

Prevailing sex ratio

Married* Prevailing sex ratio

Children*Prevailing sec ratio

Only Daughters*Prevailing sex ratio

\begin{tabular}{|c|c|c|c|c|}
\hline Prevailing sex ratio & $\begin{array}{c}\text { Coefficient } \\
11.16 \\
(3.57)^{* * *}\end{array}$ & $\begin{array}{c}\text { Marginal Effect } \\
.18 \\
(.07)^{* * *}\end{array}$ & $\begin{array}{c}\text { Coefficient } \\
11.32 \\
(3.63)^{* * *}\end{array}$ & $\begin{array}{c}\text { Marginal Effect } \\
.19 \\
(.07)^{* * *}\end{array}$ \\
\hline Married* Prevailing sex ratio & $(3.57)^{* *}$ & $(.06)^{* *}$ & $\begin{array}{c}-7.62 \\
(3.69)^{* *}\end{array}$ & $(.06)^{* *}$ \\
\hline Children*Prevailing sec ratio & & & $(.42)^{* *}$ & $\left(_{(.007)^{* *}}\right.$ \\
\hline Only Daughters*Prevailing sex ratio & & & $\begin{array}{l}-.26 \\
(.54)\end{array}$ & $\begin{array}{c}-.004 \\
(.009)\end{array}$ \\
\hline Standard Controls & & Yes & & Yes \\
\hline Behavior Controls & & Yes & & Yes \\
\hline Big Five Controls & & Yes & & Yes \\
\hline Provincial Fixed Effects & & Yes & & Yes \\
\hline Pseudo R-squared & & .38 & & .38 \\
\hline $\mathrm{N}$ & & 1006 & & 1006 \\
\hline
\end{tabular}

(1)

(2)

Notes: We report coefficients and marginal effects from logistic regressions. The calculation of the marginal effects is corrected for choice-based sampling using the method of prior correction, see King and Zeng (2001). The controls used are those used in Table 3 and controls for risk and time preferences and Big 5 personality traits. All specifications include provincial fixed effects. Standard errors are clustered by prefecture. ${ }^{* * *}$ indicates significance at $1 \%$ level, $* *$ at $5 \%$ level, ${ }^{*}$ at $10 \%$ level.

Table 7: What Type of Crime is Driven by the Sex Ratio?

\begin{tabular}{lcccc}
\hline & Violent Crime & Sexual Offence & Economic Crime \\
Prevailing sex ratio & -.29 & .04 & .72 & Economic Crime \\
& $(.44)$ & $(.08)$ & $(.43)^{*}$ & \\
Single*Prevailing sex ratio & & & & $(.14)^{* * *}$ \\
& & & & .02 \\
Married*Prevailing sex ratio & & & & $(.67)$ \\
& & & & \\
\hline & & Yes & Yes & Yes \\
Standard Controls & Yes & Yes & Yes & Yes \\
Behavior Controls & Yes & Yes & Yes & Yes \\
Big Five Controls & Yes & Yes & Yes & Yes \\
Provincial Fixed Effects & Yes & Yes & Yes & Yes \\
City of Arrest & Yes & 700 & 708 & 708 \\
Dummy for single Offence & 708 & 0.14 & 0.06 & 0.06 \\
N & 0.15 & & & \\
Pseudo R-squared & & & & \\
\hline
\end{tabular}

Notes: We report marginal effects from logistic regressions. The sample is restricted to only those who are prisoners. The controls used are those used in Table 3 and controls for risk and time preferences and Big 5 personality traits. All specifications include provincial fixed effects. Standard errors are clustered by prefecture. ***indicates significance at $1 \%$ level, $* *$ at $5 \%$ level, ${ }^{*}$ at $10 \%$ level. 
Table 8: Is the Sex Ratio a Determinant of Criminality? - Instrumental Variable Results

\begin{tabular}{|c|c|c|c|c|}
\hline \multirow[b]{2}{*}{ Prevailing sex ratio } & \multicolumn{2}{|r|}{ (1) } & \multicolumn{2}{|r|}{$(2)$} \\
\hline & $\begin{array}{c}\text { Coefficient } \\
38.1 \\
(12.33)^{* * *}\end{array}$ & $\begin{array}{c}\text { Marginal effect } \\
.18 \\
(.07)^{* * *}\end{array}$ & $\begin{array}{c}\text { Coefficient } \\
16.57 \\
(10.22)\end{array}$ & $\begin{array}{c}\text { Marginal effect } \\
.23 \\
(.15)\end{array}$ \\
\hline Individual Controls & & No & & Yes \\
\hline Prefecture Controls & & No & & Yes \\
\hline Number of Clusters & & 162 & & 162 \\
\hline Provincial Fixed Effects & & Yes & & Yes \\
\hline F-test for 1 st stage strength of IV & & 4.33 & & 10.05 \\
\hline Pseudo R-squared & & 0.06 & & 0.31 \\
\hline $\mathrm{N}$ & & 1006 & & 1006 \\
\hline
\end{tabular}

Notes: We report coefficients and marginal effects from instrumental variables logistic regressions. We instrument for the sex ratio using an interaction between the inverse of the ethnic minority share and a variable reflecting the severity of the implementation of the policy. Standard errors are bootstrapped using 1000 repetitions and allow for clustering by prefecture. Column 2 includes the controls used in Table 3. All specifications include provincial fixed effects. ***indicates significance at $1 \%$ level, ${ }^{* *}$ at $5 \%$ level, $*$ at $10 \%$ level. 


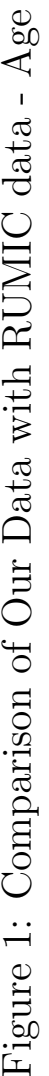




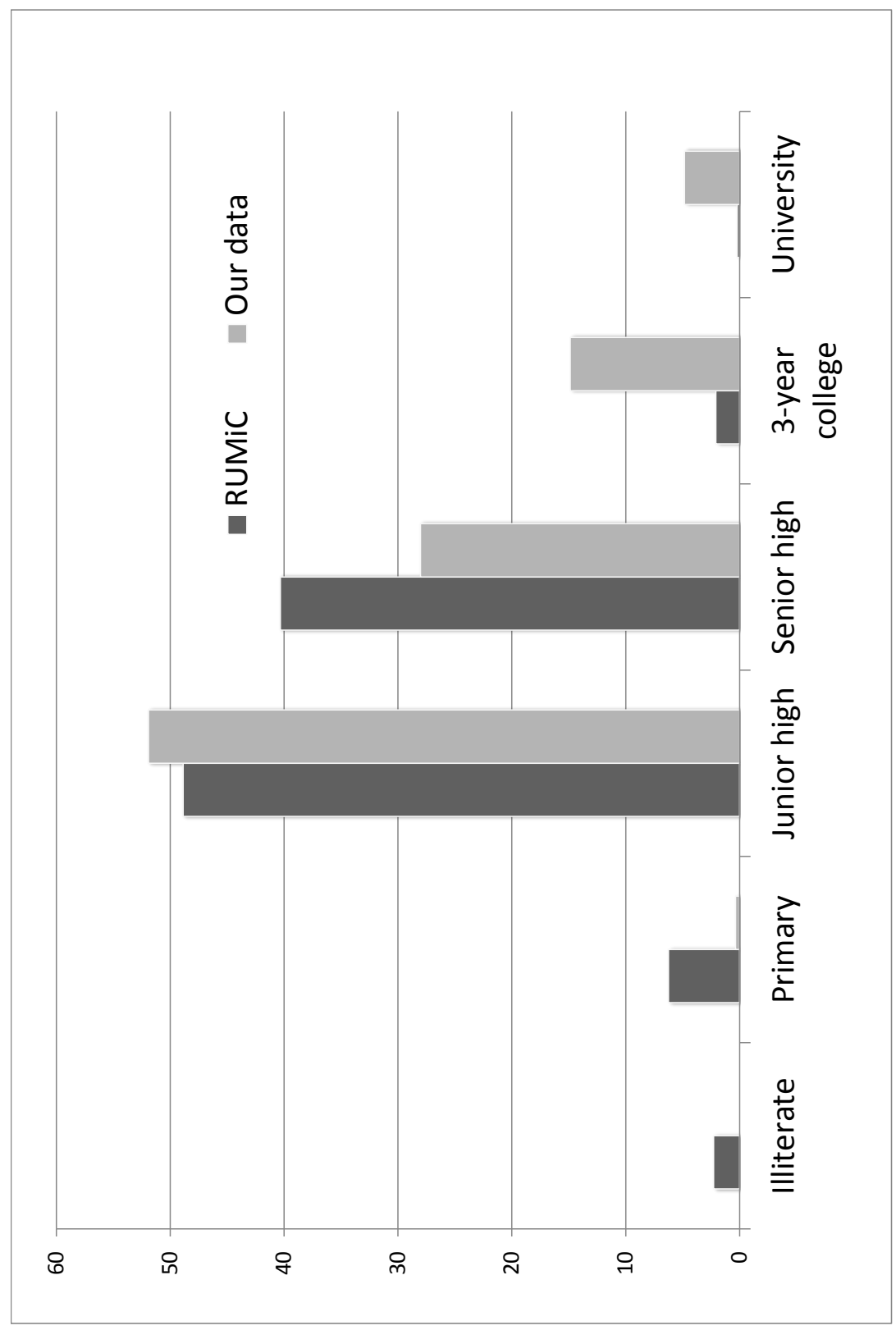

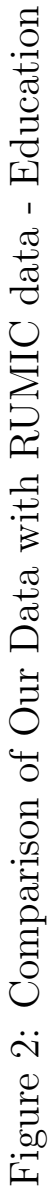




\section{A Appendix Tables}

\section{A.1 Calculation of Migrant and Prison Populations}

From the Social and Economic Development Statistical Report we know that in 2012 there were 767,130,000 migrant residents of Shenzhen (with non-local hukou). If we assume that about $90 \%$ of these are rural-urban migrants and about half are male, then we have an estimate of 3.45 million rural-urban male migrants in Shenzhen.

The same data source tells us that there were 50,315 arrests made in Shenzhen in 2012 and 2013. Using the prison administration data we calculate a prison inflow ratio (= inflow in 2012/2013 divided by the total number of prisoners in this period) of 0.55 . By dividing the total number of arrests in Shenzhen in $2012 / 2013$ by this inflow rate we obtain an estimate of the rural-urban migrant prison population in the city $=50,315 / 0.55=91,481$. The China Statistical Yearbook (2004-2013) tells us that in $201294.17 \%$ of prisoners are male. So our estimate of the male prison population is 86,148 . 
Table A1: Weighted versus Unweighted Logistic Regressions

\begin{tabular}{|c|c|c|c|c|}
\hline \multicolumn{5}{|c|}{ Dependent Variable: Prisoner $(0 / 1)$} \\
\hline & \multicolumn{2}{|c|}{ Unweighted } & \multicolumn{2}{|c|}{ Weighted } \\
\hline & coeffs & m.e.s & coeffs & m.e.s \\
\hline Prevailing sex ratio & $\begin{array}{l}8.15 \\
(3.3)^{* *}\end{array}$ & $(.05)^{* *}$ & $\begin{array}{c}5.8 \\
(3.26)^{*}\end{array}$ & $(.11$ \\
\hline Age & $\begin{array}{l}.003 \\
(.02)\end{array}$ & $\begin{array}{l}.0001 \\
(.0002)\end{array}$ & $\begin{array}{l}-.02 \\
(.03)\end{array}$ & $\begin{array}{l}-.0003 \\
(.0005)\end{array}$ \\
\hline Years of education & $(.05)^{-.52}$ & $\left(\begin{array}{c}-.008 \\
(.002)^{* * *}\end{array}\right.$ & $(.11 .02)^{* * *}$ & $(.003)^{-.02}$ \\
\hline IQ test score & $\begin{array}{l}.03 \\
(.04)\end{array}$ & $\begin{array}{l}.0004 \\
(.0005)\end{array}$ & $\begin{array}{l}-.05 \\
(.04)\end{array}$ & $\begin{array}{l}-.001 \\
(.0008)\end{array}$ \\
\hline Married & $\left(\begin{array}{l}-1.34 \\
(.29)^{* * *}\end{array}\right.$ & $(.006)^{-.02 * *}$ & $\begin{array}{l}-1.34 \\
(.39)^{* * *}\end{array}$ & $(.008)^{-.02}$ \\
\hline Number of children & $(.18)^{* * *}$ & $\begin{array}{c}.009 \\
(.003)^{* * *}\end{array}$ & $(.4)^{* *}$ & $(.004)^{* *}$ \\
\hline Father's years of education & $\begin{array}{l}-.001 \\
(.02)\end{array}$ & $\begin{array}{l}-.000 \\
(.0004)\end{array}$ & $\begin{array}{l}.05 \\
(.04)\end{array}$ & $\begin{array}{l}.001 \\
(.0008)\end{array}$ \\
\hline Mother's years of education & $(-.03)^{* *}$ & $(.0005)^{* *}$ & $(.04)^{* * *}$ & $(.0009)^{* *}$ \\
\hline Log of per capita GDP & $\begin{array}{l}.43 \\
(.42)\end{array}$ & $\begin{array}{l}.006 \\
(.006)\end{array}$ & $\begin{array}{l}.13 \\
(.7)\end{array}$ & $\begin{array}{l}.002 \\
(.01)\end{array}$ \\
\hline Gini coefficient & $\begin{array}{c}3.1 \\
(2.88)\end{array}$ & $\begin{array}{l}.05 \\
(.05)\end{array}$ & $\begin{array}{c}4.56 \\
(5.73)\end{array}$ & $\begin{array}{l}.08 \\
(.1)\end{array}$ \\
\hline Out-migration rate & $\begin{array}{l}-.03 \\
(.03)\end{array}$ & $\begin{array}{l}-.0004 \\
(.0004)\end{array}$ & $\begin{array}{l}-.01 \\
(.05)\end{array}$ & $\begin{array}{l}-.0002 \\
(.0009)\end{array}$ \\
\hline Minority population share & $\begin{array}{c}3.19 \\
(.93)^{* * *}\end{array}$ & $\begin{array}{c}.05 \\
(.02)^{* * *}\end{array}$ & $\begin{array}{c}4.08 \\
(1.09)^{* * *}\end{array}$ & $(.02)^{.07 * *}$ \\
\hline Riskiest & $(.26)^{* * *}$ & $(.004)^{* * *}$ & $\begin{array}{c}1.04 \\
(.31)^{* * *}\end{array}$ & $(.006)^{* * *}$ \\
\hline Least-patient & $\begin{array}{l}.28 \\
(.22)\end{array}$ & $\begin{array}{l}.004 \\
(.003)\end{array}$ & $\begin{array}{l}.38 \\
(.31)\end{array}$ & $\begin{array}{l}.007 \\
(.005)\end{array}$ \\
\hline $\mathrm{N}$ & & & & \\
\hline Pseudo R-squared & & & & \\
\hline
\end{tabular}

Notes: The calculation of the marginal effects in the unweighted regressions is corrected for choice-based sampling using the

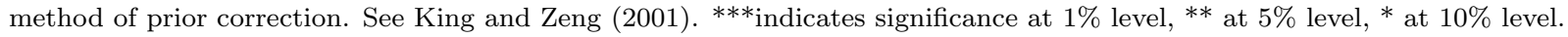


Table A2: Sensitivity to Length of Time in Prison

\begin{tabular}{|c|c|c|c|c|}
\hline \multirow[b]{2}{*}{ Panel A: Without Controls } & \multicolumn{2}{|c|}{ Patience } & \multicolumn{2}{|c|}{ Risk-Loving } \\
\hline & Continuous & Least Patient & Continuous & Riskiest \\
\hline Prevailing sex ratio & $\begin{array}{l}-2.23 \\
(2.15)\end{array}$ & $\begin{array}{l}.35 \\
(.25)\end{array}$ & $\begin{array}{l}1.94 \\
(1.41)\end{array}$ & $\begin{array}{l}.31 \\
(.25)\end{array}$ \\
\hline Time spent in prison & $\begin{array}{l}.13 \\
(.18)\end{array}$ & $\begin{array}{l}.002 \\
(.02)\end{array}$ & $\begin{array}{l}-.11 \\
(.11)\end{array}$ & $\begin{array}{r}-.003 \\
-(.01)\end{array}$ \\
\hline Total sentence length & $\begin{array}{l}-.01 \\
(.06)\end{array}$ & $\begin{array}{l}-.0008 \\
(.006)\end{array}$ & $\begin{array}{l}.05 \\
(.04)\end{array}$ & $\begin{array}{l}-.0006 \\
(.006)\end{array}$ \\
\hline $\mathrm{N}$ & 1006 & 1006 & 1006 & 1006 \\
\hline R-squared & .01 & .02 & .05 & .04 \\
\hline \multicolumn{5}{|l|}{ Panel B: With Controls } \\
\hline Prevailing sex ratio & $(2.17)^{-4 *}$ & $(.25)^{* *}$ & $\begin{array}{c}2.35 \\
(1.65)\end{array}$ & $(.28)^{*}$ \\
\hline Time spent in prison & $\begin{array}{l}.14 \\
(.18)\end{array}$ & $\begin{array}{l}.004 \\
(.02)\end{array}$ & $(. .11)$ & $\begin{array}{l}.002 \\
(.01)\end{array}$ \\
\hline Total sentence length & $\begin{array}{l}-.02 \\
(.06)\end{array}$ & $\begin{array}{l}-.0005 \\
(.005)\end{array}$ & $\begin{array}{l}.05 \\
(.04)\end{array}$ & $\begin{array}{l}-.0006 \\
(.006)\end{array}$ \\
\hline Age & $\begin{array}{l}.03 \\
(.03)\end{array}$ & $\begin{array}{l}-.003 \\
(.003)\end{array}$ & $\begin{array}{l}.02 \\
(.02)\end{array}$ & $\begin{array}{l}-.003 \\
(.003)\end{array}$ \\
\hline Years of education & $\begin{array}{l}-.06 \\
(.05)\end{array}$ & $\begin{array}{l}-.003 \\
(.006)\end{array}$ & $(.0 .11)^{* *}$ & $\begin{array}{l}-.004 \\
(.006)\end{array}$ \\
\hline IQ test score & $\begin{array}{l}-.1 \\
(.06)\end{array}$ & $\begin{array}{l}-.0002 \\
(.006)\end{array}$ & $(.05)^{* * *}$ & $\begin{array}{l}-.008 \\
(.006)\end{array}$ \\
\hline Married & $\begin{array}{l}.33 \\
(.38)\end{array}$ & $\begin{array}{l}-.001 \\
(.04)\end{array}$ & $\begin{array}{l}-.31 \\
(.26)\end{array}$ & $(.06)^{*}$ \\
\hline Number of children & $\begin{array}{l}-.13 \\
(.22)\end{array}$ & $\begin{array}{l}.005 \\
(.02)\end{array}$ & $\begin{array}{l}.07 \\
(.17)\end{array}$ & $\begin{array}{l}-.02 \\
(.02)\end{array}$ \\
\hline Father's years of education & $\begin{array}{l}-.04 \\
(.04)\end{array}$ & $\begin{array}{l}-.003 \\
(.005)\end{array}$ & $\begin{array}{l}-.04 \\
(.03)\end{array}$ & $\begin{array}{l}-.004 \\
(.004)\end{array}$ \\
\hline Mother's years of education & $\begin{array}{l}.03 \\
(.04)\end{array}$ & $\begin{array}{l}.004 \\
(.005)\end{array}$ & $\begin{array}{l}.01 \\
(.03)\end{array}$ & $\begin{array}{l}.003 \\
(.004)\end{array}$ \\
\hline Log of Prefecture GDP & $(.53)$ & $\begin{array}{c}.06 \\
(.03)^{*}\end{array}$ & $\begin{array}{l}.14 \\
(.27)\end{array}$ & $\begin{array}{l}.05 \\
(.03)^{*}\end{array}$ \\
\hline Gini coefficient & $\begin{array}{l}-3.94 \\
(2.84)\end{array}$ & $\begin{array}{l}.11 \\
(.33)\end{array}$ & $(2.44)$ & $\begin{array}{l}.22 \\
(.3)\end{array}$ \\
\hline Out-migration rate & $\begin{array}{l}.008 \\
(.03)\end{array}$ & $\begin{array}{l}-.0008 \\
(.003)\end{array}$ & $\begin{array}{l}.009 \\
(.02)\end{array}$ & $\begin{array}{l}-.003 \\
(.002)\end{array}$ \\
\hline Minority population share & $\begin{array}{l}-1.61 \\
(.85)^{*}\end{array}$ & $(.26)$ & $\begin{array}{l}.34 \\
(.54)\end{array}$ & $\begin{array}{l}.14 \\
(.09)\end{array}$ \\
\hline $\mathrm{N}$ & 1006 & 1006 & 1006 & 1006 \\
\hline R-squared & .03 & .03 & .08 & .05 \\
\hline
\end{tabular}

Notes: All specifications also control for prisoner as a correction for choice-based sampling, see Solon et al. (2015). All specifications include provincial fixed effects. Standard errors are clustered by prefecture.***indicates significance at $1 \%$ level, ** at $5 \%$ level, * at $10 \%$ level. 


\begin{tabular}{|c|l|l|}
\hline & \multicolumn{1}{|c|}{ A } & \multicolumn{1}{|c|}{ B } \\
\hline 1 & $\begin{array}{l}\text { To get 1000 Yuan after } \\
\text { one month }\end{array}$ & $\begin{array}{l}\text { To get 1025 Yuan after } \\
\text { seven months }\end{array}$ \\
\hline
\end{tabular}
\begin{tabular}{|c|l|l|}
\hline 2 & $\begin{array}{l}\text { To get } 1000 \text { Yuan after } \\
\text { one month }\end{array}$ & $\begin{array}{l}\text { To get } 1075 \text { Yuan after seven } \\
\text { months }\end{array}$ \\
\hline
\end{tabular}

\begin{tabular}{|c|c|c|}
\hline 3 & $\begin{array}{l}\text { To get } 1000 \text { Yuan after } \\
\text { one month }\end{array}$ & $\begin{array}{l}\text { To get } 1125 \text { Yuan after seven } \\
\text { months }\end{array}$ \\
\hline 4 & $\begin{array}{l}\text { To get } 1000 \text { Yuan after } \\
\text { one month }\end{array}$ & $\begin{array}{l}\text { To get } 1175 \text { Yuan after seven } \\
\text { months }\end{array}$ \\
\hline 5 & $\begin{array}{l}\text { To get } 1000 \text { Yuan after } \\
\text { one month }\end{array}$ & $\begin{array}{l}\text { To get } 1225 \text { Yuan after seven } \\
\text { months }\end{array}$ \\
\hline 6 & $\begin{array}{l}\text { To get } 1000 \text { Yuan after } \\
\text { one month }\end{array}$ & $\begin{array}{l}\text { To get } 1275 \text { Yuan after seven } \\
\text { months }\end{array}$ \\
\hline 7 & $\begin{array}{l}\text { To get } 1000 \text { Yuan after } \\
\text { one month }\end{array}$ & $\begin{array}{l}\text { To get } 1325 \text { Yuan after seven } \\
\text { months }\end{array}$ \\
\hline 8 & $\begin{array}{l}\text { To get } 1000 \text { Yuan after } \\
\text { one month }\end{array}$ & $\begin{array}{l}\text { To get } 1375 \text { Yuan after seven } \\
\text { months }\end{array}$ \\
\hline 9 & $\begin{array}{l}\text { To get } 1000 \text { Yuan after } \\
\text { one month }\end{array}$ & $\begin{array}{l}\text { To get } 1425 \text { Yuan after seven } \\
\text { months }\end{array}$ \\
\hline 10 & $\begin{array}{l}\text { To get } 1000 \text { Yuan after } \\
\text { one month }\end{array}$ & $\begin{array}{l}\text { To get } 1475 \text { Yuan after } \\
\text { seven months }\end{array}$ \\
\hline 11 & $\begin{array}{l}\text { To get } 1000 \text { Yuan after } \\
\text { one month }\end{array}$ & $\begin{array}{l}\text { To get } 1525 \text { Yuan after } \\
\text { seven months }\end{array}$ \\
\hline
\end{tabular}

Figure A1: Time Preference Choices 


\begin{tabular}{|c|c|c|}
\hline & Choice A & Choice B \\
\hline 1 & 45 Yuan for sure & $\begin{array}{l}60 \text { if you roll 1,2,3 } \\
0 \text { if you roll 4,5,6 }\end{array}$ \\
\hline 2 & 45 Yuan for sure & $\begin{array}{l}75 \text { if you roll 1,2,3 } \\
0 \text { if you roll 4,5,6 }\end{array}$ \\
\hline 3 & 45 Yuan for sure & $\begin{array}{l}90 \text { if you roll 1,2,3 } \\
0 \text { if you roll 4,5,6 }\end{array}$ \\
\hline 4 & 45 Yuan for sure & $\begin{array}{l}105 \text { if you roll } 1,2,3 \\
0 \text { if you roll } 4,5,6\end{array}$ \\
\hline 5 & 45 Yuan for sure & $\begin{array}{l}120 \text { if you roll 1,2,3 } \\
0 \text { if you roll 4,5,6 }\end{array}$ \\
\hline 6 & 45 Yuan for sure & $\begin{array}{l}135 \text { if you roll 1,2,3 } \\
0 \text { if you roll 4,5,6 }\end{array}$ \\
\hline 7 & 45 Yuan for sure & $\begin{array}{l}150 \text { if you roll 1,2,3 } \\
0 \text { if you roll 4,5,6 }\end{array}$ \\
\hline 8 & 45 Yuan for sure & $\begin{array}{l}165 \text { if you roll 1,2,3 } \\
0 \text { if you roll } 4,5,6\end{array}$ \\
\hline 9 & 45 Yuan for sure & $\begin{array}{l}180 \text { if you roll 1,2,3 } \\
0 \text { if you roll } 4,5,6\end{array}$ \\
\hline 10 & 45 Yuan for sure & $\begin{array}{l}195 \text { if you roll 1,2,3 } \\
0 \text { if you roll 4,5,6 }\end{array}$ \\
\hline 11 & 45 Yuan for sure & $\begin{array}{l}210 \text { if you roll } 1,2,3 \\
0 \text { if you roll } 4,5,6\end{array}$ \\
\hline
\end{tabular}

Figure A2: Risk Game Choices 